\begin{tabular}{l}
\hline JeMAS 13 (1) (2017) 50-59 \\
Jurnal Kesehatan Masyarakat
\end{tabular}

\title{
THE BODY SIZE AND MICRONUTRIENTS STATUS AMONG THE BRIDE-TO BE IN PROBOLINGGO DISTRICT OF EAST JAVA
}

\author{
Sri Sumarmi ${ }^{\circledR}$, Nunik Puspitasari ${ }^{2}$, Soenarnatalina Melaniani ${ }^{2}$ \\ ${ }^{1}$ Departement of Health Nutrition, Faculty of Public Health, Universitas Airlangga, Surabaya \\ ${ }^{2}$ Departement of Biostatistic and Demography, Faculty of Public Health, Universitas Airlangga, Surabaya
}

\begin{tabular}{l} 
Info Artikel \\
\hline Article History: \\
Submitted February 2017 \\
Accepted July 2017 \\
Published July 2017 \\
\hline Keywords: \\
Body size; BMI; hemo- \\
globin; serum ferritin; \\
serum retinol; serum zinc \\
\hline DOI \\
http://dx.doi.org/10.15294/ \\
kemas.v13i1.8918 \\
\hline
\end{tabular}

\begin{abstract}
Micronutrients deficiency is prevalent among women in reproductive age, particularly in developing countries, including in Indonesia. Small body size reflects a chronic deficiency of nutrients intake. Both of those problems may correlate each other and making maternal nutrition more complicated. Brides-to be are the most important group of women in reproductive age who require better recognition, because they will become mothers. This study was to describe inter-correlation among anthropometric indices which reflected the maternal body size and several indicators of micronutrient status. A cross sectional study was conducted in selected sub-districts of Probolinggo District, East Java Province year 2012. The samples size of 115 brides-to be were randomly selected from list of brides-to be in Sub-district Office of Religious Affair. The observed variables were body weight, height, body mass index (BMI), mid upper arms circumference (MUAC), micronutrients status including concentration of hemoglobin, serum ferritin, serum retinol and serum zinc. Pearson correlation test was used to analyze data using SPSS for Window version 13.0. Result showed that the average of body weight was $47,3 \mathrm{~kg}$, average stature was $150,4 \mathrm{~cm}$, BMI was 20 , MUAC was $25,3 \mathrm{~cm}$. The average of hemoglobin level was $12,4 \mathrm{~g} / \mathrm{dL}$, serum ferritin was $50,6 \mu \mathrm{g} / \mathrm{L}$, serum retinol level was $1,06 \mu \mathrm{mol} / \mathrm{L}$, and serum $\mathrm{Zn}$ level was $12,9 \mu \mathrm{mol} / \mathrm{L}$. Statistical analisis showed significant correlation between the body weight and hemoglobin concentration $(r=0,25, p=0,01)$ and serum retinol $(r=0,21, p=0,03)$; between BMI and hemoglobin concentration $(r=0,31, p=0,00)$ and serum ferritin $(\mathrm{r}=0,23, \mathrm{p}=0,03)$, and serum retinol $(\mathrm{r}=0,21, \mathrm{p}=0,02)$; between MUAC and hemoglobin $(\mathrm{r}=0,32, \mathrm{p}=0,00)$ and serum retinol $(r=0,24, p=0,02)$; between hemoglobin concentration and serum ferritin concentration $(r=$ $0,30, p=0,00)$. Stature did not correlate with any indicators of micronutrient. It implies that among the indices of body size, body weight and BMI as well as MUAC are important indicators relating to iron status, and vitamin A status, but not zinc status.
\end{abstract}

\section{Introduction}

Protein energy deficiency and micronutrients deficiency are a problem occurred in pregnant women and reproductiveage women in several countries, exclusively in region of South-Central Asia. In some Central Asia countries, more than $10 \%$ of reproductiveage women have a height less than $145 \mathrm{~cm}$. Prevalence of maternal under nutrition that are women with body mass index (BMI) below $18.5 \mathrm{~kg} / \mathrm{m}^{2}$, varies from $10 \%$ to $19 \%$ in different countries. Meanwhile, in South-East Asia, the prevalence of nutritional deficiency in women group was more than 20\% (Black, 2008).

Riskesdas data in 2013 showed the prevalence of chronic energy deficiency risk in pregnant women aged 15-49 years amounted to $24.2 \%$ nationally. The prevalence of obese women (> 18 years) amounted to $32.9 \%$, increased $18.1 \%$ since 2007 (13.9\%), or increased $17.5 \%$ from 2010 (15.5\%) (Irawati, et al., 2013; Balitbangkes, 2010, Balitbankes, 2007). Although national data on the prevalence of micronutrient deficiency in Indonesia is not yet fully available, but several studies showed high micronutrient deficiency problems. Research conducted in East Nusa Tenggara showed a high proportion of zinc deficiency in pregnant women (serum zinc level $<70 \mathrm{ug} / \mathrm{L}$ ) was about $71 \%$, while in West Java, Central Java, and Lombok was 70-90\% (Sri Sumarmi et al., 2003). Globally, Indonesia was among countries with a high prevalence of zinc deficiency, which was more than 25\% (Wessels, 2012).

Alamat korespondensi:

Fakultas Kesehatan Masyarakat, Universitas Airlangga, Surabaya

Email : msrisumarmi@gmail.com 
Prevalence data of vitamin A deficiency of Indonesian reproductive-age women was still limited. The data obtained from Helen Keller Indonesia, by clinical manifestations, showed that prevalence of night blindness was fairly high in reproductive-age women in rural area of East Java and of South Sulawesi, and in Surabaya shanty town was higher than $5 \%$ (Sari, 2004). Available prevalence data of vitamin A deficiency was in Indonesian toddlers. In 2006, the average of subclinical vitamin A deficiency prevalence in toddlers (Vitamin A serum < $20 \mathrm{ug} / \mathrm{dl}$ ) of 7 provinces (West Sumatra, South Sumatra, Banten, Bali, West Nusa Tenggara, South Kalimantan, and South-East Sulawesi) was $11.4 \%$ (Herman, 2007)

Several studies suggested an association between Iron deficiency or other micronutrients (such as Zinc (Zn), vitamin A, and vitamin C) and the body lipid deposition (Garcia, 2009; 2012; Aderibigbe, 2014). But the other studies showed the association between nutritional deficiency and anemia (Qin, 2013; Anticona, 2014). Sri Sumarmi (2016), presented that underweight as the risk factor affecting the occurrence of depleting of Iron storage in the body. A Philippian study demonstrated that body mass index in girls correlated negatively with provitamin A level and vitamin E level (Ribaya-Mercado, 2008).

Body size of women included body weight, height, and nutritional status that represented as a BMI, as a predictor of the neonatal birth weight had been documented (Neggers, 2003). Iron status and several micronutrients status also affected a pregnancy and its outcomes. Both animal studies and human observational studies evidenced that micronutrients deficiency in pre-pregnancy or during pregnancy was associated with a poor pregnancy or neonate (Ronnenberg, 2004; Bodnar, 2006; Catove, 2007; Beard, 2007; Sri Sumarmi, 2015). The low quality of the newborn baby was probably caused by not a single micronutrient deficiency, but by multiple micronutrients deficiency (Sunawang, 2009; Bhutta, 2009; Cetin, 2010; Kawai, 2011; Black, 2013).

Considering the importance of maternal nutritional status and micronutrients status in pre-pregnancy or during pregnancy, this study aimed to analyze the correlation between body size, nutritional status, and micronutrients status in the brides-to-be. By studying the association between body size and micronutrient status, these parameters would explain the importance of micronutrients, especially Iron, Zinc, and vitamin $\mathrm{A}$ in regulating body composition. Besides, it was possible to estimate the deficiency of micronutrients based on feasibility of body size measurement.

\section{Method}

A cross-sectional study was conducted in 9 Sub-districts of Probolinggo District, East Java, in 2012. The study protocol had been approved by ethical commission of Faculty of MedicineUniversitas Gadjah Mada, Yogyakarta, by a release of Ethical Clearance No. KE/FK/202/ EC. We informed the respondents aboutstudy objectives. After listening and understanding, the respondents agreed to participate in the study by signing an informed consent.

Probolinggo District was selected as the location of study considering the high prevalence of nutritional problems in the married reproductive-age women, especially Chronic Energy Deficiency by $27.3 \%$ and anemia by $48.5 \%$ (Sri Sumarmi, 2010), while percentage of anemia in brides-to-be was 15\% (Putri, 2013). Samples of 115 brides-tobe that selected randomly from the data lists documented at Religious Affairs Office(KUA), were met inclusion criteria: group aged 16 to 35 years old, physically health checked by medical examination in Primary health care (Puskesmas), and not pregnant. The sample size was calculated by Sample Size Software version 2.0.

The observed body size variables were body weight, height, BMI, upper arm circumference (UAC), whereas the observed micronutrient variables were hemoglobin levels, serum ferritin levels, serum retinol levels, and serum $\mathrm{Zn}$ levels. The body weight was measured using digital scale Seca ${ }^{\circ}$ type 803 with a level of accuracy of 100 grams. Height was measured using microtoise with a level of accuracy of 0.1 $\mathrm{cm}$. BMI was calculated as the ratio of weight in kilograms and height in meters per square (kg/ $\mathrm{m}^{2}$ ). For the brides-to-be who were younger than 20, nutritional status was assessed by BMI for age (De Onis, 2007), while for the brides- 
to-be who were older than 20, was assessed by WHO criteria (Gibson, 2005). Hemoglobin levels were measured from fingertip capillary blood, analyzed using a portable device HemoCue $\mathrm{AB}$ of Anglehome, Sweden. Serum ferritin levels were obtained from venous blood samples, and were analyzed by Micro Particle Enzyme Immunoassay (MEIA) using Axym MEIA. Serum retinol levels were analyzed by High Performance Liquid Chromatography (HPLC). Serum levels of $\mathrm{Zn}$ were analyzed using atomic absorption spectrophotometry (AAS) method. Analysis of serum ferritin levels was conducted at Laboratory of Prodia Surabaya, while the analysis of serum retinol levels and serum $\mathrm{Zn}$ levels were conducted at Laboratory of SEAMEO-RECFON Jakarta.

Anemia was assessed from hemoglobin level less than $12 \mathrm{~g} / \mathrm{dL}$, while iron deficiency or depletion of iron storage condition was defined by serum ferritin level less than 15 $\mathrm{mg} / \mathrm{L}$ (WHO, 2007). Vitamin A deficiency was assessed by serum retinol levels less than 0.7 $\mathrm{mol} / \mathrm{L}$ (WHO, 2011), while Zn deficiency was assessed from serum $\mathrm{Zn}$ levels less than 10,1 $\mu \mathrm{mol} / \mathrm{L}$ (Wessells, 2012).

Data was managed using the SPSS for Windows Version 13.0 Statistical Software Package (SPSS Inc., Chicago, IL, USA). Data normality test was performed to the entire data using a one-sample Kolmogorov-Smirnov test. The test result showed a normal distribution of data ( $p>0.05)$. Bivariate correlation analysis using Pearson correlation was conducted to observe a strong correlation between body size variables (weight, height, BMI and UAC) and micronutrient status (the levels of hemoglobin, serum levels of ferritin, serum levels of retinol, and serum levels of zinc).

\section{Results and Discussion}

Characteristics of respondents observed in this study included age, education level, occupation, and income. Detailed data was presented in Table 1.

Table 1 showed that most respondents classified as young or younger than 25 years, which was around $80 \%$, while the rest were over 25 years old. Age considered as an important variable because of the diversity of age would affect the diversity of physiology (Guyton, 2006) and the rate of protein energy metabolism and other nutrients (Stipanuk, 2006). Therefore, age was one of the dependent variables. How to control the age diversity was by including age factor in the inclusion criteria for the respondents. Respondents in this study were women ranged from 16 to 35 years. This age restriction was regarding the reproductiveage of women.

The education level of most respondents was classified at the level of basic education: education of 9 years or until the Junior High School. Most respondents were unemployment, therefore they had noincome, and less than $40 \%$ of respondents were working. Most of the no income respondents were teachers and labors. The majority of employed respondents obtained low income $\leq 1$ million.

Table 2 presented the value of descriptive statistics of the body size variable which included weight, height, BMI, and UAC measurements, as well as the concentrations of several micronutrients in the serum, such as levels of hemoglobin in the blood, the serum levels of ferritin, serum levels of retinol, and serum levels of $\mathrm{Zn}$. Data was presented in average value \pm standard deviations (SD) and range.

Respondent's weight ranged from $29 \mathrm{~kg}$ to $72.2 \mathrm{~kg}$, with an average value of $47.3 \mathrm{~kg}$ and SD of $8.6 \mathrm{~kg}$. The respondents average height was $150.4 \mathrm{~cm}$ with SD of $5.6 \mathrm{~cm}$. BMI ranged from 15.4 to 34.5 with an average value of 20.9 and SD of 3.7. The smallest UAC was $16.5 \mathrm{~cm}$ while the largest UAC was $35.3 \mathrm{~cm}$, with an average value of $25.3 \mathrm{~cm}$.

The weight was rarely used as a single parameter for assessing the nutritional status, but the women weight before pregnancy could be a predictor of neonatal birth weight. The combination of the weight to the height into a BMI was a good predictor of neonatal birth weight (Neggers, 2003; Nahar, 2007; IOM, 2009). Nahar (2007), used the weight as a single indicator in early pregnancy by under the threshold of $45 \mathrm{~kg}$ was sensitive to risk a low birth weight (LBW). Another study used women weight before pregnancy by threshold of $40 \mathrm{~kg}$ as a risk factor for low birth weight (Sri Sumarmi, 2016).

Unlike body weight, body height is known as sensitive indicator to predict 
Table 1. Socio-economic Characteristics of Respondents

\begin{tabular}{lll}
\hline Variable & $\mathrm{n}(115)$ & $\%$ \\
\hline Age (years) & 40 & 34,8 \\
$<20$ & 55 & 47,8 \\
$20-25$ & 20 & 17,4 \\
$>25$ & & \\
Education Level & 1 & 0,9 \\
No education & 17 & 14,8 \\
Elementary & 29 & 25,2 \\
Junior High School & 48 & 41,7 \\
Senior High School & 20 & 17,4 \\
University & & \\
Occupation & 76 & 66,1 \\
Unemployment & 16 & 13,9 \\
Teacher & 13 & 11,2 \\
Labor & 3 & 2,6 \\
Health worker & 3 & 2,6 \\
Farmer & 4 & 3,6 \\
Others & & \\
Income (IDR) & 76 & 66,1 \\
No income & 22 & 19,1 \\
< 500 000 & 13 & 11,3 \\
500 000 - 1000 000 & 3 & 2,6 \\
$>$ 1000 000 - 2000 000 & 1 & 0,9 \\
$>$ 2000 000 & & \\
\hline
\end{tabular}

Source: primary data

Table 2. Body size and levels of micronutrients of the respondents

\begin{tabular}{lll}
\hline Variables & $\mathrm{N}$ & $\mathrm{x} \pm \mathrm{SD}($ range $)$ \\
\hline Body size & & \\
$\quad$ weight $(\mathrm{kg})$ & 115 & $47,3 \pm 8,6(29,0-72,2)$ \\
$\quad$ height $(\mathrm{cm})$ & 115 & $150,4 \pm 5,6(136,5-164,5)$ \\
$\quad$ body mass index & 115 & $20,9 \pm 3,7(15,4-34,5)$ \\
$\quad$ upper arm circumference $(\mathrm{cm})$ & 115 & $25,3 \pm 3,5(16,5-35,3)$ \\
$\quad$ Iron status & & \\
$\quad$ haemoglobin $(\mathrm{g} / \mathrm{dL})$ & 115 & $12,4 \pm 1,14(9,1-15,7)$ \\
$\quad$ ferritin $(\mu \mathrm{g} / \mathrm{L})$ & 115 & $50,6 \pm 35,7(3,2-188,3)$ \\
$\quad$ Vitamin A status & 115 & $1,06 \pm 0,27(0,41-1,81)$ \\
$\quad$ serum retinol $(\mu \mathrm{mol} / \mathrm{L})$ & & \\
$\quad$ Zn status & 115 & $12,9 \pm 3,7(4,6-22,03)$ \\
$\quad$ serum Zn $(\mu \mathrm{mol} / \mathrm{L})$ & &
\end{tabular}

Source: primary data 
gestation outcome. Short body height less than $145 \mathrm{~cm}$ (short stature) is risk factor for gestation outcome and delivery. Women with short stature were likely to have cepalopelvic disproportion (Black, 2014). Women with body height less than $145 \mathrm{~cm}$ deliver baby with lower birth weight than women with body height more than $145 \mathrm{~cm}$ (Sri, 2016). Nahar (2017), use $150 \mathrm{~cm}$ as cut off for body height.

This study use hemoglobin level and serum feritin to determine iron body status. Respondent have hemoglobin level between 9,1 g/dL to $15,7 \mathrm{~g} / \mathrm{dL}$, with mean and standard deviation $12,4 \mathrm{~g} / \mathrm{dL}$ and $1,14 \mathrm{~g} / \mathrm{dL}$, respectively. Serum feritin level means are categorized as good with $50,6 \mu \mathrm{g} / \mathrm{L}$, and wide range from $3,2 \mu \mathrm{g} / \mathrm{L}$ to $188,3 \mu \mathrm{g} / \mathrm{L}$. From hemoglobin and serum feritin means, we can conclude respondent have normal iron body status. Non anemia hemoglobin level, which is above 12 $\mathrm{g} / \mathrm{dL}$, whereas serum feritin means above 15 $\mu \mathrm{g} / \mathrm{L}$ and below $60 \mu \mathrm{g} / \mathrm{L}$ mean respondent have enough iron body storage or normal repleted (WHO, 2007)

Retinol and $\mathrm{Zn}$ serum levels represent vitamin $\mathrm{A}$ and $\mathrm{Zn}$ status. Respondents retinol serum level range are between $0,41 \mu \mathrm{mol} / \mathrm{L}$ to $1,81 \mu \mathrm{mol} / \mathrm{L}$, with mean value $1,06 \mu \mathrm{mol} / \mathrm{L}$. Whereas Zn serum level mean value is 12,9 $\mu \mathrm{mol} / \mathrm{L}$ with range between from $4,6 \mu \mathrm{mol} / \mathrm{L}$ to $22,03 \mu \mathrm{mol} / \mathrm{L}$. From Retinol and $\mathrm{Zn}$ means level, our respondent vitamin $\mathrm{A}$ and $\mathrm{Zn}$ status are categorized as good and have no deficiency. Vitamin A and Zn deficiency are a condition where retinol and $\mathrm{Zn}$ serum level are less than $0,7 \mu \mathrm{mol} / \mathrm{L}$ and $10,1 \mu \mathrm{mol} / \mathrm{L}$ respectively (Gibson,2005). Subclinical vitamin A deficiency happen when retinol serum level is less than 0,7 $\mu \mathrm{mol} / \mathrm{L}$ without clinical sign evidence. (WHO, 2011)

Table 3. shows respondent percentage based on nutritional, anemia, iron storage, vitamin $\mathrm{A}$, and $\mathrm{Zn}$ status. From nutritional status, there were $23,5 \%$ underweight, and $12,2 \%$ overweight respondents. About 33\% respondents suffered anemia, mostly from mild anemia without any from severe anemia. Most of respondent had sufficient iron storage $(\geq 15$ $\mu \mathrm{g} / \mathrm{L}$ ) from feritin serum level, whereas $15,7 \%$ had depleted iron storage. Retinol serum level

Table 3. Respondent distribution by nutrition and micro-nutrient status

\begin{tabular}{lll}
\hline Variable & $\mathrm{n}(115)$ & $\%$ \\
\hline Nutrition status $(\mathrm{BMI})$ & 27 & 23,5 \\
Underweight & 74 & 64,3 \\
Normal & 11 & 9,6 \\
Overweight & 3 & 2,6 \\
Obese & & \\
Anemia Status & 0 & 0,0 \\
Severe Anemia $(\mathrm{Hb}<8 \mathrm{~g} / \mathrm{dL})$ & 3 & 2,6 \\
Moderate Anemia $(\mathrm{Hb} 8-10 \mathrm{~g} / \mathrm{dL})$ & 35 & 30,4 \\
Mild Anemia $(\mathrm{Hb} 10,1-11,9 \mathrm{~g} / \mathrm{dL})$ & 77 & 67,0 \\
No Anemia $(\geq 12 \mathrm{~g} / \mathrm{dL})$ & & \\
Iron storage status & 18 & 15,7 \\
Depleted $(f e r i t i n<15 \mu \mathrm{g} / \mathrm{L})$ & 56 & 48,7 \\
Normal $($ feritin $15-60 \mu \mathrm{g} / \mathrm{L})$ & 41 & 35,6 \\
Excess $(\mathrm{feritin} \geq 60 \mu \mathrm{g} / \mathrm{L})$ & & \\
Vitamin A Status & 8 & 7,0 \\
Deficiency $(\mathrm{retinol}<0,7 \mu \mathrm{mol} / \mathrm{L})$ & 107 & 93,0 \\
Normal $($ retinol $\geq 0,7 \mu \mathrm{mol} / \mathrm{L})$ & & \\
Zn Status & 30 & 26,1 \\
Deficiency $(\mathrm{Zn}<10,1 \mu \mathrm{mol} / \mathrm{L})$ & 85 & 73,9 \\
Normal $(\mathrm{Zn} \geq 10,1 \mu \mathrm{mol} / \mathrm{L})$ &
\end{tabular}

Source : Primary Data 
showed $7 \%$ respondents had subclinical vitamin A deficiency, and from $\mathrm{Zn}$ serum level there were $26,1 \%$ respondents showed $\mathrm{Zn}$ deficiency.

Underweight percentage in this study $(23,5 \%)$ was higher than national prevalence of underweight in adult women $(9,4 \%)$ based on Riskesdas 2013 (Irawati, 2013). Compared with Utami (2012), study, our study underweight percentage was lower. In comparison overweight and obesity percentage on respondent in this study was lower $(12,2 \%)$ than national prevalence in adult women $(32,9 \%)$ based on Riskesdas 2013 (Irawati, 2013)

Anemia percentage (hemoglobin less than $12 \mathrm{~g} / \mathrm{dL}$ ) in our respondent about $33 \%$, mostly were mild anemia (hemoglobin between 10,1-11,9 g/dL) $30,4 \%$ and without severe anemia case found. Anemia prevalence in this study and female teenager in West Lombok, Nusa Tenggara Barat were similar (Masthalia, 2015), but higher compared with Riskesdas 2013, about 22,7\% (Balitbangkes, 2010). 15,7\% of respondent suffered low or depleted iron storage. Low iron storage in body (less than 15 $\mu \mathrm{g} / \mathrm{L}$ ) indicates iron deficiency states (WHO, 2017). In conclusion almost half of respondent who suffer anemia in this study $(14,3 \%)$ were anemia non iron deficiency, which caused by other micro-nutrient deficiency.

About $7 \%$ of respondent suffer vitamin A deficiency (retinol serum level less than $0,7 \mu \mathrm{mol} / \mathrm{L}$ ). This percentage was higher than vitamin A deficiency in reproductive female age in Cambodia which were 0,7\% (Wieringa, 2016). But respondents had lower percentage of vitamin A deficiency than primary school age female in Marliyati study (2014), in the amount of $58,1 \%$. Whereas $\mathrm{Zn}$ deficiency percentage in this study $(26,1 \%)$ was higher than reproductive age female in Mexico, that were $17,4 \%$ (Garcia,2012).

Table 4. shows the result of statistical analyze using Pearson correlation on body size that include body weight, body height, body mass index, and upper arm circumference with hemoglobin level, ferritin serum level, retinol serum level, and $\mathrm{Zn}$ serum level. The result showed correlation between body size parameter which statistically significant had correlation with hemoglobin level were body weight, body mass index, and upper arm circumference. Whereas that has statistically significant correlation correlation with ferritin serum levelwas only body mass index. While in retinol serum level case, body weight, body mass index, and upper arm circumference all have statistically significant correlation. While there were no body size parameter that had statistically significant correlation with $\mathrm{Zn}$ serum level.

Body mass index and upper arm circumference had significant positive correlation with hemoglobin level at level of confidence $\alpha=0,01$ with correlation coefficient $r=0,31$, and $r=0,32$ respectively and $p$ value $\mathrm{p}<0,001$. Which means the higher body mass index and upper arm circumference, hemoglobin level will also higher. This result was similar with other study in China (Qin, 2013), also in Bangladesh (Kamruzzaman, 2013). Theoretically, body mass index and upper arm circumference can reflect nutritional status, which is the manifestation of adequacy in energy and protein diet. The first step in heme synthesis is condensation of glycine and succynil Co-A to form $\delta$-aminolevulinic acid (ALA) with ALA synthase enzyme help which activated by vitamin B6 in pyridoxal phosphate form (Ajioka, 2006). Succinyl Co-A is the result of carbohydrate and fat catabolism via tricarboxylate acid (TCA) cycle (Stipanuk, 2006).

Body mass index had weak correlation with ferritin serum level $(r=0,23 ; p=0,03)$. This result differed with some previous study. Aderibigbe (2014), explain that iron deficiency had correlation with fat deposit in body or called adiposity. Micronutrient deficiency also ascociated with obesity and fat deposit. Therefore, micronutrient deficiency may coexisted with obesity (Garcia, 2009). Adipose tissue produce pro-inflammatory cytokines such as interleukin-1, interleukin-6, and Tumor Necrosis Factor- $\alpha$ (TNF $\alpha)$ and also adipokines (leptin, adiponectin, resistin) that influence iron balance in the body (Zekanowska, 2011).

Some body size parameter such body weight, body mass index, and upper arm circumference have positive correlation with retinol serum level. This study differed from Ribaya-Mercado (2008), in Philippine that showed there was no correlation between 
body mass index with retinol serum level, because retinol serum that circulate in blood, physiologically controlled by vitamin A concentration in liver. Also body mass index has negative correlation with carotenoid and vitamin $\mathrm{E}$ level. This phenomenon can be explained that body mass index is a predictor of body fat composition while vitamin A and carotenoid is lipid-soluble compound that stored in liver and fat

There were no body size parameter that had correlation with $\mathrm{Zn}$ serum level. This result correspond with Ibekwe (2013), study in Nigeria that showed that there was no relation between anthropometric parameter with $\mathrm{Zn}$ serum level in female teenager. As other study, also showed no relation between $\mathrm{Zn}$ level in plasm with body mass index in Mexico's women (Garcia, 2012).

\section{Conclusion}

High percentage of underweight, overweight (BMI > 25), and also micro-nutrient deficiency, especially anemia and $\mathrm{Zn}$ deficiency were found among future brides in Probolinggo district, East Java. Some of body size parameter, such as body weight, body mass index, and upper arm circumference have positive correlation with iron status (hemoglobin and ferritin level) and vitamin A status (retinol serum level), but have no correlation with $\mathrm{Zn}$ status. Body height has no correlation with micro-nutrient status. These can deduced body size parameter that correlate with body fat composition is sensitive to show change in micro-nutrient status, unlike body height that not correlated with body composition, moreover is a long term parameter that not sensitive to show short term change in micro-nutrient status.

\section{Acknowledgement}

Our gratitude belongs to Indonesian Danone Institute Foundation for funding this study. Head of Bappeda and head of Probolinggo district Public Health Office and his crew, also Prodia Surabaya Laboratory staff and Medicine Faculty UI SEAMEO-RECFON laboratory staff, and all other party that help this study proceed successfully.

\section{References}

Aderibigde OR, Pisa PT, Vorster HH, and Kruger SH. 2014. The Relationship between Iron Sttaus And Adiposity in Women From Developing
Countries: a review. Crit Rev Food Sci Nutr. 28(3):553-560.

Ajioka RS, Phillips JD, Kushner JP. 2006. Biosynthesis of Heme in Mammals. Biochimica et Biophysica Acta. 1763: 723-736.

Anticona C \& Sebastian MS. 2014. Anemia and Malnutrition in Indegenous Children and Adolescents of the Peruvian Amazon in a Context of Lead Exposure: a cross-sectional study. Glob Health Action 7: 22888.

Black RE, et al. 2008. Maternal and Child Undernutrition: Global and Regional Exposures and Health Consequences. The Lancet. 371 (9608):243-260.

Black RE, et al. and the Maternal and Child Nutrition Study Group. 2013. Maternal and Child Undernutrition And Overweight in Low-Income and Middle-Income Countries. The Lancet. 382 (9890):427-451.

Balitbangkes. 2010. Riset Kesehatan Dasar (Riskesdas) Tahun 2010. Balitbangkes, Kementerian RI. Jakarta.

Balitbangkes. 2007. Riset Kesehatan Dasar (Riskesdas) Tahun 2007. Balitbangkes, Kementerian RI. Jakarta.

Beard J. 2007. Recent Evidence from Human and Animal Studies Regarding Iron Status and Infant Development. J Nutr.137:524S-530S.

Bhutta ZA, et al. 2009. A Comparative Evaluation of Multiple Micronutrient and Iron-Folic Acid Supplementation During Pregnancy in Pakistan: impact on pregnancy outcomes. Food Nutr Bull, 30(Suppl):S496-505.

Bodnar LM, et al. 2006. Periconceptional Multivitamin Use Reduces the Risk of Preeclampsia. Am J Epidemiol. 164: 470-477.

Catove JM, et al. 2007. Association of periconceptional multivitamin use and risk of preterm or small-for-gestational-age births. Am J. Epidemiol.166(3):296-303.

Cetin I, et al. 2010. Role of Micronutrients in the Periconceptional Period. Human Reproduction Update, 16(1): 80-95.

De Onis M, et al.. 2007. Development of a WHO Growth Reference for School-Age Children and Adolescents. Buletin of WHO 85:660667.

Garcia OP, Long KZ, Rosado JL. 2009. Impact of Micronutrient Deficiencies on Obesity. Nutr Rev. 67(10):559-572.

García OP, et al. 2012. Zinc, vitamin A, and Vitamin C Status are Associated with Leptin Concentrations and Obesity in Mexican Women: Results From A Cross-Sectional Study. Nutr Metab (Lond). 9:59.

Gibson RS. 2005. Principles of Nutritional Assessment 
$2^{\text {nd }}$ Edition. New York: Oxford University Press.

Guyton AC and Hall JE. 2006. Textbook of Medical Physiology $11^{\text {th }}$ edition. Phyladephia: Elsevier Saunders.

Herman S. 2007. Masalah Kurang Vitamin A (KVA) dan Prospek Penanggulangannya. Media Litbang Kesehatan, 17(4):35-42.

Ibekwe MU and Ibekwe RC. 2013. Correlation between Seerum Zinc Level and Height of Adolescence School Girls in a Nigerian community. Niger J Paed. 40(3):243-247.

Institute of Medicine. 2009. Weight Gain During Pregnancy: Reaxamining the Guidelines. Rassmusen $\mathrm{M}$ and Yaktine AL (Eds). Washington DC: National Academies Press.

Irawati A, et al. 2013. Riset Kesehatan Dasar (Riskesdas) Tahun 2013. Badan Penelitian dan Pengembangan Kesehatan, Kementerian Kesehatan RI. Jakarta.

Kamruzzaman, et al. 2015. Differentials in the Prevalence of Anemia Among NonPregnant, Ever-Married Women in Bangladesh: Multilevel Logistic Regression Analysis Of Data From The 2011 Bangladesh Demographic and Health Survey. BMC Women's Health 15: 54.

Kawai, et al. 2011. Maternal Multiple Micronutrient Supplementation And Pregnancy Outcomes In Developing Countries: Meta-Analysis And Meta-Regression. Bull World Health Organ, 89:402-411B.

Masthalina H, Laraeni Y, dan Dahlia YP. 2015. Pola konsumsi (faktor inhibitor dan enhancer $\mathrm{Fe})$ terhadap status anemia remaja putri. KESMAS. 11(1): 80-86.

Marliyati SA, Nugraha A dan Anwar F. 2014. Asupan Vitamin A, Status Vitamin A, dan Status Gizi Anak Sekolah Dasar di Kecamatan Leuwiliang, Kabupaten Bogor. Jurnal Gizi dan Pangan. 9(2): 109-116

Neggers Y dan Goldenberg RL. 2003. Some Thoughts On Body Mass Index, Micronutrient Intake And Pregnancy Outcome. Am J Clin Nutr.133: 1737S-1740S.

Nahar S, Mascie-Taylor CG, Begum HA. 2007. Maternal Anthropometry as a Predictor of Birth Weight. Public Health Nutr. 10(9):96570.

Putri SI \& Sri Sumarmi. 2013. Perbandingan Konsumsi Zat Gizi, Status Gizi dan Kadar Hemoglobin Pengantin Wanita di Wilayah Pantai dan Pertanian Kabupaten Probolinggo. Media Gizi Indonesia. 9(1):72-77.

Qin Y, et al. 2013. Anemia in Relation to body Mass Index and Waist Circumeference Among
Chinese Women. J Nutr 12: 10.

Ronnenberg AG, et al. 2004. Preconception Hemoglobin and Ferritin Concentration are Associated with Pregnancy Outcome in a Prospective Cohort of Chinese Women. J Nutr.134:2586-91.

Ribaya-Mercado JD, et al. 2008. Relationship of Body Mass Index with Serum Carotenoids, Tocopherol And Retinol At Steady-State and in Response to Carotenoid-Rich Vegetable Diet Intervention in Filipino Schoolchildren. Biosci Rep. 28(2):97-106.

Sari M, de Pee S, Halati S, Martini E, Bloem MW. 2004. Risk factors for Night Blindness Among Non-Pregnant Women In Indonesia. Paper Presented at the XXII IVACG Meeting and 2004 INACG Symposium. Lima-Peru. 15-18 November 2004.

Sri Sumarmi, et al. 2003. Pengaruh Pemberian Seng $(\mathrm{Zn})$ pada Ibu Hamil terhadap Status Seng dan Berat Bayi Lahir. Media Medika Inonesiana. 38 (1):25-36.

Sri Sumarmi, et al. 2010. Baseline Survey on Nutritional Status Among Women in Reproductive Age. Report. Planning and Development Board of District Government of Probolinggo: Probolinggo East Java.

Sri Sumarmi, et al. 2015. Micronutrients supplementation During Preconception Period Improves Fetal Survival And Cord Blood Insulin-Like Growth Factor-1. Asian J Nutr.7(2):33-44.

Sri Sumarmi. 2016. Maternal Short Stature and Neonatal Stunting: an Inter-Generational Cycle of Malnutrition. Proceeding. International Conference of Health and Well-being. Surakarta, Mei 2016.

Sri Sumarmi, et al. 2016. Underweight as a risk Factor for Iron Depletion and Iron- Deficient Erythropoiesis Among Young Women in Rural Areas of East Java, Indonesia. Mal J Nutr. 22 (2) : 219-23 2.

Stipanuk MH. 2006. Biochemical, Physiological, Molecular Aspects of Human Nutrition $2^{\text {nd }}$ edition. St. Louis Missouri: Saunders Elsevier.

Sunawang UB, Utomo B, Hidayat A, Kusharisupeni, Subarkah. 2009. Preventing low birthweight Through Maternal Multiple Micronutrient Supplementation: a cluster-randomized, controlled trial in Indramayu, West Java. Food Nutr Bull. 30(Suppl):S488-95.

Utami SR. 2012. Status Gizi, Kebugaran Jasmani dan Produkstivitas Kerja pada Tenaga Kerja Wanita. KESMAS. 8(1):74-80.

Wessells KR, Brown KH. 2012. Estimating the global prevalence of zinc deficiency: Results based 
on zinc availability in national food supplies and prevalence of stunting. PLoS ONE. 7(11)

Wieringa FT, et al. 2016. Low Prevalence of Iron and vitamin A Deficiency Among Cambodian Women of Reproductive Age. Nutrients. 8(4): 197.

World Health Organization. 2007. Assessing the Iron Status of Population 2nd Edition: Report Of A Joint World Health Organization/Centers for Disease Control and Prevention Technical
Consultation on Assessment of Iron Status at the Population Level. Geneva: WHO.

World Healath Organization. 2011. Serum Retinol Concentrations for Determining the Prevalence of Vitamin A Deficiency in Populations. Geneva: WHO.

Żekanowska E, Boinska J, Giemza-Kucharska P, Kwapisz J. 2011. Obesity and Iron Metabolism. BioTechnologia, 92(2):147-152. 